Jurnal Hukum Saraswati (JHS),Volume. 03, Nomor 02, (2021)

FAKULTAS HUKUM UNMAS DENPASAR

ISSN (Cetak) : 2715-758X ISSN (Online): 2720-9555

Doi: https://doi.org/10.36733/jhshs.v2i2

https://e-journal.unmas.ac.id/index.php/JHS

UNMAS DENPASAR

\title{
EKSISTENSI HUKUMAN MATI DITINJAU DARI ASPEK HAM SIPIL DALAM PERSEPEKTIF HAK UNTUK HIDUP
}

\author{
I Gusti Bagus Hengki 1), I Made Kariyasa ${ }^{2)}$, Anak Agung Adi Lestari ${ }^{3)}$ \\ ${ }^{122) 33}$ Fakultas Hukum Universitas Mahasaraswati Denpasar \\ E-mail: bagushengkifh@unmas.ac.id ${ }^{1)}$
}

\section{Abstract}

This scientific paper is expected to find out how the existence of the death penalty is viewed from the aspect of Civil Human Rights in the perspective of the right to life and whether the existence of the death penalty is contrary to the ideology of the Pancasila State and the 1945 Constitution of the Republic of Indonesia and the Human Rights Law with a normative research methodology with using a statutory approach. From the results of the discussion that the existence of the death penalty in terms of the Civil Human Rights aspect in the perspective of the right to life still needs to be maintained, because it does not conflict with the ideology of the Pancasila State and the 1945 Constitution of the Republic of Indonesia, the Human Rights Law, UDHR and ICCPR, as well as religion. in Indonesia, as long as it is not carried out arbitrarily, in accordance with the provisions of the legislation. This needs to be done because to provide protection for individual perpetrators and victims against acts of revenge, emotional, uncontrollable, vigilante, so that it does not guarantee that the death penalty is abolished. Indeed, there are parties who are pro and contra about the death penalty by both underpinning Pancasila, all of which is to make Pancasila a "Justification".

Keywords: Existence, Death Penalty, Civil Human Rights

\begin{abstract}
Abstrak
Tulisan ilmiah ini diharapkan dapat mengetahui bagaimana eksistensi hukuman mati ditinjau dari aspek HAM Sipil dalam perspektif hak untuk hidup dan apakah eksistensi hukuman mati bertentangan dengan ideologi Negara Pancasila dan Undang-Undang Dasar Negara Republik Indonesia Tahun 1945 serta UndangUndang HAM dengan metodologi penelitian normatif dengan menggunakan jenis pendekatan perundang-undangan (statute Approach). Dari hasil pembahasan bahwa eksistensi hukuman mati ditinjau dari aspek HAM Sipil dalam perspektif Hak untuk hidup masih perlu dipertahankan, karena tidak bertentangan dengan ideologi Negara
\end{abstract}


Jurnal Hukum Saraswati (JHS),Volume. 03, Nomor 02, (2021)

FAKULTAS HUKUM UNMAS DENPASAR

ISSN (Cetak) : 2715-758X ISSN (Online): 2720-9555

Doi: https://doi.org/10.36733/jhshs.v2i2

https://e-journal.unmas.ac.id/index.php/JHS

73

Pancasila dan Undang-Undang Dasar Negara Republik Indonesia Tahun 1945, Undang-Undang HAM, UDHR dan ICCPR, maupun agama yang ada di Indonesia, asal dilaksanakan tidak sewenang-wenang, sesuai dengan ketentuan peraturan perundang-undangan. Hal ini perlu diadakan karena untuk memberikan perlindungan terhadap individu pelaku dan korban terhadap tindakan balas dendam, emosional, tidak terkendali, main hakim sendiri, sehingga tidak menjamin bahwa kalau hukuman pidana mati ditiadakan. Memang ada pihak yang pro dan kontra tentang hukuman mati dengan sama-sama mendasari Pancasila, semuanya itu untuk menjadikan Pancasila sebagai "Justification".

Kata Kunci : Eksistensi, Hukuman mati, HAM Sipil

\section{A. Pendahuluan}

Bahwa manusia dianugerahi oleh

Tuhan Yang Maha Esa akal budi dan nurani yang memberikan kepadanya kemampuan untuk membedakan yang baik dan yang buruk yang akan membimbing dan mengarahkan sikap dan perilaku dalam menjalani kehidupannya. Dengan akal budi dan nuraninya itu, maka manusia memiliki kebebasan untuk memutuskan sendiri perilaku dan perbuatannya. Disamping itu untuk mengimbangi kebebasan tersebut manusia manusia memiliki kemampuan untuk bertanggung jawab atas segala tindakan yang dilakukannya.

Kebebasan dasar dan hak-hak dasar itulah yang disebut hak asasi manusia yang melekat pada manusia secara kodrati sebagai anugerah Tuhan Yang Maha Esa. Hak-hak ini tidak dapat diingkari . Pengingkaran terhadap hak tersebut berarti mengingkari martabat kemanusiaan. Oleh karena itu negara, pemerintah atau organisasi apapun mengemban kewajiban untuk mengakui dan melindungi hak asasi manusia pada setiap manusia tanpa kecuali. Ini berarti bahwa hak asasi manusia harus selalu menjadi titik tolak dan tujuan dalam penyelenggaraan kehidupan bermasyarakat, berbangsa dan bernegara.

Sejalan dengan pandangan di atas, Pancasila sebagai dasar ideologi negara mengandung pemikiran bahwa Manusia diciptakan oleh Tuhan Yang Maha Esa dengan menyandang dua 
Jurnal Hukum Saraswati (JHS),Volume. 03, Nomor 02, (2021)

FAKULTAS HUKUM UNMAS DENPASAR

ISSN (Cetak) : 2715-758X ISSN (Online): 2720-9555

Doi: https://doi.org/10.36733/jhshs.v2i2

https://e-journal.unmas.ac.id/index.php/JHS

74

aspek yakni, aspek individualitas (pribadi) dan aspek sosialitas (bermasyarakat). Oleh karena itu, kebebasan setiap orang dibatasi oleh hak asasi orang lain. Ini berarti bahwa setiap orang mengemban mengakui dan menghormati hak orang lain. Kewajiban ini juga berlaku bagi setiap organisasi pada tatanan manapun, terutama negara dan pemerintah. Dengan demikian negara dan pemerintah bertanggung jawab untuk menghormati, melindungi, dan membela hak asasi manusia setiap warga negara dan penduduknya tanpa diskriminan.

Kewajiban menghormati hak asasi manusia tersebut, tercermin dalam Pembukaan Undang-Undang Dasar Negara Republik Indonesia Tahun 1945 yang menjiwai keseluruhan pasal dalam batang tubuhnya, terutama berkaitan dengan persamaan kedudukan warga negara dalam hukum dan pemerintahan, hak atas pekerjaan dan penghidupan yang layak, kemerdekaan berserikat dan berkumpul, hak untuk mengeluarkan pikiran dengan lisan dan tulisan, kebebasan memeluk agama dan

beribadat sesuai dengan agama dan kepercayaannya itu, hak untuk memperoleh pendidikan dan pengajaran, hak untuk hidup serta berhak mempertahankan hidup dan kehidupan.

Disisi lain Negara Republik Indonesia dalam Kitab UndangUndang Hukum Pidana (WvS ) dan Undang-Undang Pidana Khusus di luar KUHP, masih memberlakukan sanksi pidana berupa hukuman mati. Banyak pihak pro dan kontra tentang masih diberlakukannya hukuman mati di Indonesia. Bagi yang kontra terhadap hukuman mati mengemukakan alasannya bahwa bertentangan dengan asas paling dasar dari semua negara hukum yaitu Ketuhanan Yang Maha Esa, Kemanusiaan dan Pri Keadilan. Bertentangan dengan tujuan Lembaga Pemasyarakatan, yang berusaha membina dan mendidik agar sewaktuwaktu narapidana bisa kembali ke masyarakat. Kalau hukuman mati telah dilaksanakan apakah mungkin si terhukum bisa kembali ke masyarakat. Dari sisi lain hukuman mati sama sekali tidak mencegah dan mengurangi jumlah 
Jurnal Hukum Saraswati (JHS),Volume. 03, Nomor 02, (2021)

FAKULTAS HUKUM UNMAS DENPASAR

ISSN (Cetak) : 2715-758X ISSN (Online): 2720-9555

Doi: https://doi.org/10.36733/jhshs.v2i2

https://e-journal.unmas.ac.id/index.php/JHS

75

kejahatan, sehingga hukuman mati Normatif dengan cirri-ciri sebagai sebenarnya tidak lebih tindakan putus asa pihak penegak hukum. Hukuman mati tidak sesuai dengan ideologi Negara Pancasila dan Undang-Undang Dasar Negara Republik Indonesia Tahun 1945, Hak-hak Sipil diantaranya hak untuk hidup, berhak mempertahankan hidup dan kehidupannya. Hak untuk hidup adalah anugerah dari Tuhan Yang Maha Esa, sehingga hanya Tuhan Yang Maha Esa berhak untuk mencabutnya, bukan dilakukan oleh manusia. Oleh karena adanya pendapat pro dan kontra tentang hukuman mati dengan berbagai argumentasinya dengan landasan negara hukum, Pancasila dan Undang-Undang Dasar Negara Republik Indonesia Tahun 1945 serta HAM, maka dalam tulisan ini akan membahas lebih lanjut persoalan tersebut di atas dengan tema : "Eksistensi Hukuman Mati Ditinjau Dari Aspek HAM Sipil Dalam Perspektif Hak Untuk hidup”. berikut :

a. Beranjak adanya kesenjangan dalam norma / asas hukum.

b. Tidak menggunakan hipotesis.

c. Menggunakan Landasan Teoritis.

d. Menggunakan bahan hukum yang terdiri dari atas bahan hukum primer dan bahan hukum sekunder ${ }^{1}$

Jenis Pendekatan Masalah.

Dalam tulisan ini menggunakan jenis pendekatan perundang-undangan ( statute Approach ) yaitu mengkaji eksistensi hukuman mati ditinjau dari aspek HAM Sipil dalam perspektif hak untuk hidup.

3. Sumber bahan hukum

Dalam tulisan ini menggunakan sumber bahan hukum yaitu :

a. Bahan hukum primer (peraturan perundang-undangan)

b. Bahan hukum sekunder (buku, jurnal, makalah dsb)

\section{B. Metode Penelitian}

Dalam penelitian ini menggunakan jenis penelitian Hukum

\footnotetext{
${ }^{1}$ Program Studi Magister Ilmu Hukum, 2006, Pedoman Penulisan dan Penelitian Tesis Ilmu Hukum, Univ Udayana, Denpasar, h.8
} 
Jurnal Hukum Saraswati (JHS),Volume. 03, Nomor 02, (2021)

FAKULTAS HUKUM UNMAS DENPASAR

ISSN (Cetak) : 2715-758X ISSN (Online): 2720-9555

Doi: https://doi.org/10.36733/jhshs.v2i2

https://e-journal.unmas.ac.id/index.php/JHS

76

c. Bahan hukum tesier (ensiklopedia, kamus hukum, kamus bahasa Indonesia)

\section{Teknik Analisis.}

Untuk menganalisa bahan-bahan hukum yang terkumpul dalam tulisan ini menggunakan teknik deskripsi adalah teknik dasar analisa yang tidak dapat dihindari penggunaannya. "Deskripsi berarti uraian apa adanya terhadap suatu kondisi atau posisi dari proposisiproposisi hukum atau non hukum" ${ }^{2}$

\section{Pembahasan}

Pembahasan dalam penulisan ini didahului dengan landasan teoritis sebagai dasar untuk mengkaji dan/atau melakukan analisis dalam penelitian hukum normatif sebagai berikut :

\section{Landasan Teoritis.}

Landasan teoritis yang digunakan dalam penulisan ini adalah Pengertian eksistensi, teori hukuman (straf theorien) yang meliputi : teori absolut atau teori pembalasan (absolute strafrecht theorien), teori relatif atau teori tujuan (doel theorien), teori

\footnotetext{
${ }^{2}$ Ibid h. 9
}

gabungan (verenigings theorien), dan peraturan perundang-undangan. Untuk jelasnya akan diuraikan berturut-turut sebagai berikut

\section{a. Pengertian Eksistensi}

Pengertian eksistensi berkaitan dengan hukuman mati sesuai dengan sub judul dari penulisan ini, sebelum kita memahami teori dan peraturan perundang-undangan tentang hukuman mati, sebaiknya kita memahami terlebih dahulu secara etimologi kata eksistensialisme. Kata eksistensialisme berasal dari kata eksistensi, eksistensi berasal dari bahasa Inggris yaitu existence, dari existere yang berarti muncul, ada, timbul, memilih keberadaan actual. Dari kata ex berari keluar dan sister yang berarti muncul atau timbul. Beberapa pengertian secara terminologi, yaitu pertama, apa yang ada, kedua, apa yang dimiliki aktualitas (ada), dan ketiga adalah segala sesuatu (apa saja) yang di dalam menekankan bahwa sesuatu itu ada. Berbeda dengan esensi yang menekankan kealpaan sesuatu (apa sebenarnya sesuatu itu sesuatu dengan kodrat 
Jurnal Hukum Saraswati (JHS),Volume. 03, Nomor 02, (2021)

FAKULTAS HUKUM UNMAS DENPASAR

ISSN (Cetak) : 2715-758X ISSN (Online): 2720-9555

Doi: https://doi.org/10.36733/jhshs.v2i2

https://e-journal.unmas.ac.id/index.php/JHS

77

inherennya) $)^{3}$.Secara umum, eksistensi

1) Teori Absolute atau teori

berarti keberadaan, muncul, ada, timbul

pembalasan

(Strafrecht

pada sesuatu.

Dari uraian tersebut di atas, penulis dapat menarik kesimpulan secara bebas bahwa pengertian eksistensi hukuman mati yang berkaitan dengan tema penulisan ini adalah keberadaan, muncul, ada, timbul berkaitan dengan hukuman mati bagi para pelaku tindak pidana berat, sedangkan beberapa negara di dunia dengan alasan HAM menghapus hukuman mati dengan hukuman seumur hidup, sedangkan di Indonesia hukuman mati masih tetap eksis keberadaannya berdasarkan peraturan perundang-perundang yang ada, misalnya UU RI No.15 Tahun 2003 tentang Penetapan Perpu No.1 Tahun 2002 tentang Pemberantasan Tindak Pidana Korupsi Menjadi UndangUndang, UU RI No.35 tentang Narkotika dsbnya.

\section{b. Teori Hukuman (straftheorien) :}

\footnotetext{
${ }^{3}$ Lorens Bagus, 2005,"Kamus Filsafat", http://digilib.uinsby.ac.id>eksistensi, diakses pada tanggal 31 Agustus 2021.
}

Menurut teori ini, setiap kejahatan harus dibalas dengan hukuman tanpa memperhatikan akibat yang mungkin timbul dari dijatuhkannya hukuman tersebut. Sehingga teori ini hanya melihat ke masa lampau, tampa memperhatikan masa yang akan datang . Penganutnya antara lain Kant dan Hegel, dua-duanya sarjana Jerman. Kant berkata, "Si pembunuh harus digantung walaupun masyarakat pada esok hari akan rusak dan pecah “. Jadi, menurut teori pembalasan ini tujuan hukuman adalah penghukuman itu sendiri.

2) Teori Relatif atau teori tujuan (does theorien)

Menurut teori ini tujuan hukuman adalah untuk mencegah terjadinya pelanggaran

hukum. Pencegahan atau prevensi, ditujukan pada :

a. Masyarakat, hukuman itu dijatuhkan dengan tujuan agar masyarakat tidak melakukan kejahatan atau pelanggaran, disebut juga sebagai prevensi umum (generale preventie).

b. Pembahasan dari segi terhukum, hukuman itu dijatuhkan dengan tujuan agar terhukum tidak mengulangi kembali perbuatan yang telah pernah dilakukannya. Dengan perkataan lain, hukuman itu dijatuhkan untuk memperbaiki 
Jurnal Hukum Saraswati (JHS),Volume. 03, Nomor 02, (2021)

FAKULTAS HUKUM UNMAS DENPASAR

ISSN (Cetak) : 2715-758X ISSN (Online): 2720-9555

Doi: https://doi.org/10.36733/jhshs.v2i2

https://e-journal.unmas.ac.id/index.php/JHS

78

diri terhukum agar tidak berbuat jahat kembali, yang disebut prevensi khusus (speciale preventie). Penganutnya antara lain, Van Hamel (Belanda ) dan Von Liszt ( Jerman ).

c. VAN HAMEL, membuat suatu gambaran tentang yang bersifat prevensi khusus itu sebagai berikut :

1) Hukuman harus memuat suatu anasir menakutkan supaya dapat menahan khusus

2) "gelegenheid misdadige" melakukan niat yang buruk.

3) Hukuman haru memuat suatu anasir yang memperbaiki bagi terhukum, yang nanti memerlukan suatu reclassering.

4) Hukuman harus memuat suatu anasir membinasakan bagi penjahat yang sama sekali tidak lagi dapat diperbaiki.

5) Tujuan satu-satunya dari hukuman ialah mempertahankan ketertiban hukum.

3) Teori Gabungan (Verenigingstheorien)

Menurut teori ini hukuman mengandung unsur pembalasan dan pencegahan terhadap terjadinya kejahatan dan pelanggaran, sehingga tata tertib masyarakat tidak terganggu, serta memperbaiki si penjahat. Penganut teori ini antara lain adalah Zevenbergen, Pompe, Hugo de Groot, Rossi dan Taverne. ${ }^{4}$

\section{c. HAM dalam Hukum Positif Indonesia.}

Seberapa jauh HAM terwujud atau merupakan bagian dari hukum positif di Indonesia, antara lain dapat diidentifikasikan dan dikaji dari pernyataan dan ketentuan perundangundangan di Indonesia sebagai berikut

1) Dalam Pembukaan UUD NRI Tahun 1945.

Pernyataan-pernyataan yang dituangkan dalam Pembukaan UUD NRI Tahun 1945 sarat dengan pernyataan (deklarasi) dan pengakuan menjunjung tinggi harkat, martabat dan nilai-nilai kemanusiaan yang sangat luhur dan sangat asasi. Antara lain ditegaskan hak setiap bangsa (termasuk individual) akan kemerdekaan, berkehidupan yang bebas, tertib dan damai, hak membangun bangsa mencapai kemakmuran dan

4 Ahkiar Salimi, 1985, Eksistensi Hukuman Mati, Aksara Persada, Jakarta, h.85 
Jurnal Hukum Saraswati (JHS),Volume. 03, Nomor 02, (2021)

FAKULTAS HUKUM UNMAS DENPASAR

ISSN (Cetak) : 2715-758X ISSN (Online): 2720-9555

Doi: https://doi.org/10.36733/jhshs.v2i2

https://e-journal.unmas.ac.id/index.php/JHS

79

kesejahteraan, berkedaulatan

bermusyawarah / ber perwakilan,

berkebangsaan, berperikemanusiaan,

3) Di dalam Perundang-undangan lainnya.

berkeadilan dan berkeyakinan

Ketuhanan Yang Maha Esa.

Pernyataan-pernyataan yang padat di dalam Pembukaan UUD NRI Tahun 1945, jelas mengandung jiwa dan semangat yang tidak jauh berbeda dengan "Universal Declaration of Human Right “ (UDHR) yang diterima pada sidang umum PBB pada tanggal 10 Desember $1948 .^{5}$

2) Di dalam Batang Tubuh UUD NRI Tahun 1945.

Walaupun tidak secara menyeluruh dan terperinci seperti UDHR, namun di dalam batang tubuh UUD NRI Tahun 1945 juga dijumpai pasal-pasal yang dapat diselaraskan dengan hak-hak asasi yang tercantum dalam UDHR sebagaimana ketentuan Bab X A Hak Asasi Manusia: Pasal 28 A sampai dengan Pasal 28 J, Pasal 29 tentang Agama dan sebagainya.

5 Barda Nawawi Arief, 2005, Bunga Rampai Kebijakan Hukum Pidana, PT. Aditya Bakti, Bandung, h.55

Hak-hak asasi manusia di dalam UDHR dapat dikatagorikan dalam 2(dua) kelompok hak yaitu : “ Civil and political rights " dan "Economic, social and cultural rights".

Kedua kelompok hak tersebut berhubungan dengan berbagai Perundang-undangan di Indonesia, misal seperti : Tap MPR No. II/MPR/1987 tentang Pedoman Penghayatan dan Pengamalan Pancasila ( P4 ), UU No.12 / 2006 tentang Kewarga negaraan, UU RI No. 10 Tahun 2016 tentang Pilkada, UU RI No $31 / 2014$ tentang Atas Perubahan UU No.13 Tahun 2006 tentang Perlindungan Saksi dan Korban, UU RI No. 23 Tahun 2004 tentang KDRT, UU RI No.17 Tahun 2016 tentang Penetapan Perpu No.1 Tahun 2016 tentang perubahan kedua UU No.23 Tahun 2002 tentang Perlindungan anak menjadi UndangUndang, dan sebagainya.

\section{d. HAM dari sudut Hukum Pidana.}

1) Dalam pedoman Penghayatan dan Pengamalan Pancasila ( Eka 
Jurnal Hukum Saraswati (JHS),Volume. 03, Nomor 02, (2021)

FAKULTAS HUKUM UNMAS DENPASAR

ISSN (Cetak) : 2715-758X ISSN (Online): 2720-9555

Doi: https://doi.org/10.36733/jhshs.v2i2

https://e-journal.unmas.ac.id/index.php/JHS

80

Prasetya Pancakarsa) ditegaskan : “ Dengan keyakinan akan kebenaran Pancasila, maka manusia ditempatkan pada keluhuran harkat dan martabatnya sebagai mahluk Tuhan Yang Maha Esa dengan kesadaran mengemban kodratnya sebagai mahluk prrbadi dan sekaligus sebagai mahluk sosial “. Dari penegasan ini jelas terlihat pengakuan dan keterjalinan antara aspek kemanusiaan dan aspek kemasyarakatan.

2) Salah satu aspek yang sangat mendasar adalah hak untuk hidup dan hak untuk melangsungkan kehidupan. Hak ini adalah paling asasi karena diberikan langsung oleh Tuhan Yang Maha Esa. Oleh karena itu setiap orang berhak untuk mempertahankan hidupnya dari serangan yang tertuju kepada keselamatan jiwanya. Maka perampasan nyawa oleh orang lain (pembunuhan) termasuk oleh negara berupa hukuman mati, pada hakikatnya melanggar HAM, apabila dilakukan sewenangwenang dan tidak sesuai dengan peraturan perundang-undangan yang berlaku.

3) Mengakui hak hidup sebagai hak yang sangat asasi, berarti perampasan hak hidup seseorang itu sekiranya terpaksa dilakukan, pad hakikatnya merupakan suatu perkecualian. Ini berarti dilihat dari sudut hukum pidana sejauh mungkin pidana mati itu dihindari. Sekiranya terpaksa dijatuhkan harus sudah melewati prosedur yang sangat ketat. Prosedur atau tahap-tahap yang sangat ketat itu, antara lain hanya dijatuhkan pada delik-delik tertentu yang dipandang sangat jahat atau sangat serius, diberikan hak untuk minta pengampunan, peringanan, penundaan atau perubahan / pergantian pidana mati setelah melalui percobaan tertentu.

4) Aspek kemanusiaan lainnya yang sangat asasi dan juga dinyatakan (dideklarasikan) di dalam Pembukaan UUD NRI Tahun 1945 
Jurnal Hukum Saraswati (JHS),Volume. 03, Nomor 02, (2021)

FAKULTAS HUKUM UNMAS DENPASAR

ISSN (Cetak) : 2715-758X ISSN (Online): 2720-9555

Doi: https://doi.org/10.36733/jhshs.v2i2

https://e-journal.unmas.ac.id/index.php/JHS

81

adalah hak kemerdekaan dan kebebasan berkehidupan.

Pembukaan UUD NRI Tahun 1945 diawali pernyataan bahwa “ kemerdekaan adalah hak segala bangsa “, Penjajahan harus dihapuskan karena tidak sesuai dengan perikemanusiaan dan perikeadilan " dan hak untuk “ berkehidupan kebangsaan yang bebas ".

5) Hak atas kemerdekaan dan kebebasan seseorang mencakup makna atau aspek atau ruang lingkup yang sangat luas. Seseorang tidak hanya bebas dan merdeka terhadap keberadaannya (eksistensinya) sebagai manusia, tetapi juga di dalam menentukan, melangsungkan dan mempertahankan eksistensinya sebagai manusia dalam kehidupan pribadi maupun kehidupan bermasyarakat., berbangsa dan bernegara.

6) Walaupun kemerdekaan dan kebebasan merupakan hak asasi manusia dan sekaligus hak asasi masyarakat, namun menurut Pembukaan UUD NRI Tahun 1945 bukanlah kebebasan yang liar dan tampa tujuan. Hak kemerdekaan dan keinginan luhur untuk berkehidupan kebangsaan (termasuk kehidupan perorangan) yang ingin dicapai adalah kebebasan dalam keteraturan atau kebebasan dalam suasana tertib (tatanan) hukum yang bertujuan mewujudkan kesejahteraan dan keadilan sosial serta perlindungan seluruh bangsa Indonesia.

7) Perampasan dan pembatasan kemerdekaan berdasarkan peraturan yang berlaku berarti ada hak terhadap orang yang ditangkap, ditahan, dijatuhi pidana perampasan kemerdekaan, mempunyai hak untuk mengetahui dasar-dasar atau alasan penangkapan, penahanan atau penjatuhan pidana atas dirinya dan juga hak untuk mendapatkan rehabilitasi atau kompensasi atas penangkapan, penahanan atau 
Jurnal Hukum Saraswati (JHS),Volume. 03, Nomor 02, (2021)

FAKULTAS HUKUM UNMAS DENPASAR

ISSN (Cetak) : 2715-758X ISSN (Online): 2720-9555

Doi: https://doi.org/10.36733/jhshs.v2i2

https://e-journal.unmas.ac.id/index.php/JHS

82

penjatuhan pidana tidak sesuai dengan hukum yang berlaku.

8) Seseorang harus dianggap tidak bersalah sebelum putusan pengadilan yang berkekuatan tetap mengenai kesalahan dan seseorang tidak dapat dipidana tanpa kesalahan.

9) Sisi lain dari asas "Tidak ada pidana tanpa kesalahan" ialah pertanggungjawaban pidana bersifat personal, pertanggungjawaban pidana hanya dikenakan kepada pelaku yang bersalah. Jadi hak personalitas ini juga dimaksudkan untuk melindungi hak orang lain yang tidak bersalah.

\section{e. Hukuman mati menurut KUHP (WvS)}

Dalam Pasal 11 KUHP ditentukan bahwa " hukuman mati dijalankan oleh algojo di tempat penggantungan, dengan menggunakan sebuah jerat di leher terhukum dan mengikatkan jerat itu pada tiang penggantungan dan menjatuhkan papan tempat orang itu berdiri”. Pelaksanaan hukuman seperti ketentuan Pasal 11 KUHP tidak dilaksanakan di Indonesia karena tidak sesuai dengan jiwa dan berkembangan revolusi bangsa Indonesia. Berdasarkan dengan Penpres RI No. 2 Tahun 1964 tentang Pelaksanaan Pidana Mati, menyatakan bahwa pelaksanaan pidana mati dilaksanakan dengan ditembak sampai mati di suatu tempat daerah hukum pengadilan yang menjatuhkan putusan dalam tingkat pertama.

\section{f. Eksistensi Pidana Mati dalam Konsep RUU KUHP.}

1. Pertama-tama fatur dikemukakan bahwa konsep KUHP ( sistem hukum pidana materiil ) dilatar belakangi oleh berbagai pokok pemikiran yang secara garis besar dapat disebut " ide keseimbangan ". Ide keseimbangan ini antara lain mencakup :

a. Keseimbangan monodualistik antara " kepentingan umum / masyarakat " dan " kepentingan individu / perorangan ".

b. Keseimbangan antara perlindungan / kepentingan pelaku 
Jurnal Hukum Saraswati (JHS),Volume. 03, Nomor 02, (2021)

FAKULTAS HUKUM UNMAS DENPASAR

ISSN (Cetak) : 2715-758X ISSN (Online): 2720-9555

Doi: https://doi.org/10.36733/jhshs.v2i2

https://e-journal.unmas.ac.id/index.php/JHS

83

tindak pidana (ide individualisasi

pidana) dan korban tindak pidana,

keseimbangan antara unsur / faktor

"objektif"

b. ( perbuatan / lahiriah ) dan “ subjektif “ (orang / batiniah /sikap batin ), ide“ daad-dader strafrecht “.

c. Keseimbangan antara kriteria "formal" dan "materiel "

d. Keseimbangan antara " kepastian hukum", " ketentuan / elastisitas /fleksibilitas “, dan " keadilan “

e. Keseimbangan nilai-nilai nasional dan nilai-nilai global / internasional / universal.

2. Bertolak dari ide keseimbangan mono dualistic, maka tujuan pemidanaan menurut konsep diarahkan pada dua sasaran pokok, yaitu " perlindungan masyarakat “ dan “ perlindungan / pembinaan individu ".

3. Dilihat dari ide dasar dan tujuan perlindungan masyarakat serta bertolak dari hasil penelitian, maka konsep tetap mempertahankan jenisjenis pidana berat, yaitu pidana mati dan penjara seumur hidup. Namun dalam kebijakan formulasinya juga mempertimbangkan perlindungan / kepentingan individu, yaitu dengan diadakannya ketentuan mengenai :

a. "Penundaan pelaksanaan pidana mati "atau "pidana mati bersyarat", yaitu pada masa percobaan (sepuluh tahun) apabila terpidana menunjukan sikap terpuji, pidana mati itu dapat diubah menjadi pidana penjara seumur hidup atau penjara dua puluh tahun .

b. Dapat dubahnya pidana penjara seumur hidup menjadi pidana penjara lima belas tahun apabila terpidana menjalani pidana minimal sepuluh tahun dengan berkelakuan baik, sehingga dimungkinkan terpidana mendapatkan "pelepasan bersyarat ".

4. Di samping pokok pemikiran di atas, dipertahankannya pidana mati juga didasarkan pada ide "menghindari tuntutan / reaksi masyarakat yang bersifat balas dendam / emosional / sewenang- 
Jurnal Hukum Saraswati (JHS),Volume. 03, Nomor 02, (2021)

FAKULTAS HUKUM UNMAS DENPASAR

ISSN (Cetak) : 2715-758X ISSN (Online): 2720-9555

Doi: https://doi.org/10.36733/jhshs.v2i2

https://e-journal.unmas.ac.id/index.php/JHS

84

wenang / tidak terkendali atau bersifat "extralegal execution"

5. Eksistensi pidana mati dilihat dari sudut pandang ideologi Negara Pancasila, amandemen kedua UUD NRI Tahun 1945 dan UU RI Nomor 39 Tahun 1999 tentang HAM yang menyatakan bahwa "Setiap orng berhak untuk hidup “ ( Pasal 28A jo Pasal 28 UUD NRI Tahun 1945 dan Pasal 9 ayat (1) jo Pasal 4 UU RI Nomor 39 Tahun 1999 tentang HAM dan "setiap orang berhak untuk bebas dari penghilangan paksa dan penghilangan nyawa “ ( Pasal 33 ayat (2) UU RI No.39 Tahun 1999 tentang $\mathrm{HAM}^{6}$

\section{g. Hak-hak Sipil dan Politik.}

Hak-hak Sipil dan Politik adalah salah satu dari golongan Hak Asasi Manusia, golongan yang lain adalah Hak-hak Sosial dan Ekonomi, Hak-hak Lingkungan dan Pembangunan. Sesuai dengan tema tulisan ini, hanya dibahas

\footnotetext{
6 Barda Nawawi Arief, 2005, Pembaharuan Hukum Pidana Dalam Persepektif Kajian Perbandingan, PT.Citra Aditya Bakti, Bandung, h.288
}

salah satu hak Sipil yaitu Hak untuk hidup. Hak-hak ini kerap dipandang sebagai inti dari Hak Asasi Manusia. "Hak Sipil adalah hak-hak yang dinikmati oleh individu. Adalah kewajiban negara untuk tidak melarang hak-hak ini. Rakyat mempunyai hak untuk hidup, kemerdekaan, kebebasan dan keamanan. Mereka juga mempunyai hak untuk diperlakukan secara adil" ${ }^{\prime 7}$

\section{h. Hukuman mati ditinjau dari aspek agama.}

1) Agama Katolik.

Ditinjau dari agama Katolik menjelaskan bahwa hukuman mati adalah sebagai berikut :

a) Gereja Katolik sebagai umat Allah tidak mempunyai pernyataan yang mendukung adanya hukuman mati.

b) Gereja Katolik berpendapat bahwa masalah hukummenghukum itu merupakan wewenang pemerintah. Hal ini

7 Mabes Polri, 2006, Buku Panduan Tentang Hak Asasi Manusia, Percetakan Polri, Jakarta, h. 21 
Jurnal Hukum Saraswati (JHS),Volume. 03, Nomor 02, (2021)

FAKULTAS HUKUM UNMAS DENPASAR

ISSN (Cetak) : 2715-758X ISSN (Online): 2720-9555

Doi: https://doi.org/10.36733/jhshs.v2i2

https://e-journal.unmas.ac.id/index.php/JHS

85

berdasarkan surat Rasul Paulus

kepada umat di Roma.

c) Gereja Katolik lebih cenderung untuk tidak menyetujui adanya hukuman mati berdasarkan Kitab suci perjanjian baru ( Injil ) yang menyempurnakan perjanjian lama.

d) Meskipun Gereja Katolik mengakui bahwa masalah hukum-menghukum itu merupakan wewenang pemerintah, namun Gereja juga memberikan pendapatnya kepada pemerintah agar seandainya hukuman mati itu dilaksanakan, hendaknya, sangat diperhitungkan tiga hal ini : keadilan (justice), kebijaksanaan (prudence) dan belas kasihan (mercy).

2) Agama Islam.

Ditinjau dari agama Islam bahwa Pidana mati itu adalah sudah ditetapkan dalam syariat Islam oleh dekrit Allah swt yang tidak dapat digugat oleh siapapun. Dasar eksistensi hukuman mbagi agama Islam adalah firman Allah SWT yang tertera dala Al-quran, antara lain terdapat pada Surat Al Baqarah ( Q.S.2 : 178 dan 179 ), Surat Al Maa Idah ( Q.s. 5 :32 ).

3) Agama Budha.

Menurut Suparto H.S. ( Ketua Perwakilan Umat Buddha Indonesia ) : "Orang Budha tidak akan kaget apabila ada orang dihukum mati "Saya melihat suatu hal yang semestinya karena adanya suatu perbuatan yang telah dilakukannya".

4) Agama Hindu.

Menurut Drs I.B. Puniatmaja (Ketua Parisada Hindu Dharma, anggota DPR dan Dosen Universitas Udayana). Kejahatan membunuh, mengambil arta dan memperkosa boleh dibalas dengan mencabut nyawa pelakunya. Orang tidak berdosa. yang mengambil nyawa orang yang bersalah. " Itulah hukum keadilan dalam agama Hindu “ Nyawa orang yang melakukan kejahatan 
Jurnal Hukum Saraswati (JHS),Volume. 03, Nomor 02, (2021)

FAKULTAS HUKUM UNMAS DENPASAR

ISSN (Cetak) : 2715-758X ISSN (Online): 2720-9555

Doi: https://doi.org/10.36733/jhshs.v2i2

https://e-journal.unmas.ac.id/index.php/JHS

86

seperti di atas dianggap tidak berguna lagi. ${ }^{8}$

\section{Hukuman mati dalam aspek HAM}

Sipil.

Hukuman mati dalam aspek

HAM Sipil, masih perlu dipertahankan baik dilihat dari sudut pandang Pancasila dan UUD 1945, UndangUndang Republik Indonesia Nomor 39 Tahun 1999 tentang HAM, aspek agama yang ada di Indonesia dan dikaitkan teori penghukuman serta sistem hukum pidana Indonesia, dengan pokok-pokok pikiran / ide dasar sebagai berikut :

a. Menghindari tuntutan / reaksi masyarakat yang bersifat balas dendam / emosional / sewenangwenang / tidak terkendali atau bersifat "extralegal/execution" artinya , disediakannya pidana mati dalam undang-undang dimaksudkan untuk memberikan saluran emosi / tuntutan masyarakat. Tidak tersedianya pidana mati dalam undangundang bukan merupakan

\footnotetext{
${ }^{8}$ Ahtiatr Salmi, OpCit h.109-114
}

jaminan tidak adanya pidana mati dalam kenyataan di masyarakat. Oleh karena itu untuk menghindari emosi balas dendam pribadi/masyarakat yang tidak rasional, dipandang lebih bijaksana apabila pidana mati tetap tersedia dalam undangundang. Dengan adanya pidana mati dalam undang-undang , diharapkan penerapannya oleh hakim akan lebih selektif dan berdasarkan pertimbangan yang rasional/terkendali. Jadi, dimaksudkan juga untuk memberi perlindungan individu/warga masyarakat dari pembalasan yang sewenangwenang dan emosional dari korban atau masyarakat apabila pidana mati tidak diatur dalam undang-undang..

b. Dilihat sebagai satu kesatuan, Pancasila mengandung nilai keseimbangan antara sila yang satu dan sila lainnya. Nemun, apabila Pancasila dilihat secara parsial (menitik beratkan pada 
Jurnal Hukum Saraswati (JHS),Volume. 03, Nomor 02, (2021)

FAKULTAS HUKUM UNMAS DENPASAR

ISSN (Cetak) : 2715-758X ISSN (Online): 2720-9555

Doi: https://doi.org/10.36733/jhshs.v2i2

https://e-journal.unmas.ac.id/index.php/JHS

salah satu sila) ada pendapat bahwa pidana mati bertentangan dengan ideologi Negara Pancasila dan ada pula yang menyatakan tidak bertentangan dengan ideologi Negara Pancasila. Jadi, pendapat yang menolak dan menerima pidana mati , sama-sama mendasarkan pada ideologi Negara Pancasila. Ada kecenderungan baik yang pro dan menolak pidana mati menggunakan ideologi Negara Pancasila sebagai “ Justification " dan UUD NRI Tahun 1945 sebagai hukum konstitusi tertinggi negara.

c. Demikian pula dalam UU RI No.39 Tahun 1999 tentang HAM ada dalam pembatasan dalam Pasal 73 menyatakan : "Hak dan kebebasan yang diatur dalam undang-undang ini hanya dapat dibatasi oleh dan berdasarkan undang-undang, semata-mata untuk menjamin pengakuan dan penghormatan terhadap hak asasi manusia serta kebebasan dasar orang lain, kesusilaan, ketertiban umum, dan kepentingan bangsa“. Pasal 73 UU RI No.39 Tahun 1999 tentang HAM ini identik dengan Pasal $28 \mathrm{~J}$ UUD NRI Tahun 1945.

\section{Hak untuk hidup dalam aspek} HAM Sipil.

"Hak untuk hidup" (Pasal 28 A jo 28 UUD NRI Tahun 1945 dan Pasal 9 ayat (1) jo Pasal 4 UU RI No.39 Tahun 1999 tentang HAM) dan " hak untuk bebas dari penghilangan nyawa (Pasal 33 UU RI No.39 Tahun 1999 tentang HAM ) tidak dapat dihadapkan secara diametral

( sama sekali bertentangan ) dengan" pidana mati". Hal ini sama dengan "hak kebebasan pribadi “ ( Pasal 4 UU RI No.39 Tahun 1999 tentang HAM ) yang juga tidak dapat dihadapkan secara diametral dengan " pidana penjara ( perampasan kemerdekaan/ kebebasan )'. Pernyataan dalam UUD NRI Tahun 1945 dan dalam UU RI No.39 Tahun 1999 tentang HAM yang menyatakan bahwa bahwa " setiap orang berhak 
Jurnal Hukum Saraswati (JHS),Volume. 03, Nomor 02, (2021)

FAKULTAS HUKUM UNMAS DENPASAR

ISSN (Cetak) : 2715-758X ISSN (Online): 2720-9555

Doi: https://doi.org/10.36733/jhshs.v2i2

https://e-journal.unmas.ac.id/index.php/JHS

88

untuk hidup “, identik dengan Pasal 6 ayat (1) ICCPR (International Covenant on Civil and Political Rights/Kovenan Internasional tentang Hak-Hak Sipil dan Politik) yang disahkan oleh Majelis Umum Perserikatan Bangsa-Bangsa pada tanggal 16 Desember 1966. .ICCPR menyatakan bahwa " setiap manusia mempunyai hak untuk hidup “, tetapi tidak berarti hak hidupnya itu tidak dapat dirampas. Yang tidak boleh adalah “ perampasan hak hidupnya secara sewenang-wenang “.

\section{Simpulan dan Saran}

Sebagai penutup dalam tulisan ini disampaikan simpulan dan saran sebagai berikut :

\section{Simpulan}

Eksistensi hukuman mati ditinjau dari aspek HAM Sipil dalam perspektif Hak untuk hidup masih perlu dipertahankan, karena tidak bertentangan dengan ideologi Negara Pancasila dan UUD RI Tahun 1945, Undang-Undang HAM, UDHR dan ICCPR, maupun agama yang ada di Indonesia, asal dilaksanakan tidak sewenang-wenang, sesuai dengan ketentuan peraturan perundang-undangan yang berlaku. Hal ini perlu diadakan karena untuk memberikan perlindungan terhadap individu pelakudan/atau korban terhadap tindakan balas dendam, emosional, tidak terkendali, main hakim sendiri atau diselesaikan melalui pengadilan masyarakat, sehingga tidak menjamin bahwa kalau hukuman pidana mati ditiadakan. Memang ada pihak yang pro dan kontra tentang hukuman mati dengan sama-sama mendasari ideologi Negara Pancasila Pancasila dan UUD NRI Tahun 1945, semuanya itu untuk menjadikan Pancasila sebagai "Justification " dan UUD NRI Tahun 1945 sebagai hukum konstitusi tertinggi negara.

\section{Saran.}

Kiranya konsep RUU KUHP Nasional lebih bijaksana dalam eksistensi hukuman mati, oleh karenanya disarankan Pemerintah Republik Indonesia segera mengesahkan konsep KUHP baru menjadi RUU selanjutnya disahkan menjadi KUHP Nasional. 
Jurnal Hukum Saraswati (JHS),Volume. 03, Nomor 02, (2021)

FAKULTAS HUKUM UNMAS DENPASAR

ISSN (Cetak) : 2715-758X ISSN (Online): 2720-9555

Doi: https://doi.org/10.36733/jhshs.v2i2

https://e-journal.unmas.ac.id/index.php/JHS

89

\section{Daftar Pustaka}

\section{Buku}

Arif, Barda Nawawi, 2005, Bunga

Rampai Kebijakan

Hukum

Pidana, PT. Citra

Aditya

Bakti, Bandung.

2005, Pembaharuan

Hukum Pidana Dalam Perspektif

Kajian Perbandingan, PT. Citra

Aditya Bakti, Bandung.

Mabes Polri, 2006, Buku Panduan

Tentang Hak Asasi Manusia,

Percetakan Polri.

Program Studi Magister Ilmu Hukum,

2006, Pedoman Penulisan dan

Penelitian Tesis Ilmu

Hukum, Univ Udayana, Denpasar.

Salimi, Ahkiari, 1985, Eksistensi Hukuman Mati, Aksara

Persada, Jakarta.

\section{Internet}

Bagus, Lorens, 2005,“Kamus Filsafat”, http://digilib.uinsby.ac.id>eksiste nsi, diakses pada tanggal

Agustus 2021.

\section{Peraturan Perundang-Undangan}

Undang-Undang Dasar Negara Republik

Indonesia Tahun 1945

Kitab Undang-Undang Hukum Pidana (KUHP)

Undang-Undang Republik Indonesia Nomor 1 Tahun 1946 tentang Peraturan Hukum

Pidana.Diumumkan oleh

Sekretaris Negara Republik Indonesia tanggal 36 Februari 1946.

UDHR (Universal Declaration of Human Right) yang diterima pada sidang umum PBB pada tanggal 10 Desember 1948

ICCPR (International Covenant on Civil and Political Rights/Kovenan Internasional tentang Hak-Hak Sipil dan Politik) yang disahkan oleh Majelis Umum Perserikatan 
Jurnal Hukum Saraswati (JHS),Volume. 03, Nomor 02, (2021)

FAKULTAS HUKUM UNMAS DENPASAR

ISSN (Cetak) : 2715-758X ISSN (Online): 2720-9555

Doi: https://doi.org/10.36733/jhshs.v2i2

https://e-journal.unmas.ac.id/index.php/JHS

90

Bangsa-Bangsa pada tanggal 16

Desember 1966

Undang-Undang Republik Indonesia

Nomor 39 tentang Hak Asasi

Manusia. Lembaran Negara

Republik Indonesia Tahun 1999

Nomor 165, Tanggal 23 September

1999. Tambahan Lembaran

Negara Republik Indonesia Nomor 3886 .

Undang-Undang Republik Indonesia

Tahun 2003 tentang Penetapan

Perpu No.1 Tahun 2002 tentang

Pemberantasan Tindak Pidana

Terorisme menjadi Undang-

Undang. Lembaran Negara

Republik Indonesia Tahun 2002

Nomor 106, Tanggal 18 Oktober

2002. Tambahan Lembaran

Negara Republik Indonesia Nomor 4232.

Undang-Undang Republik Indonesia Nomor 23 Tahun 2004 tentang

Kekerasan Dalam Rumah Tangga.

Lembaran Negara Republik
Indonesia Tahun 2004 Nomor 95, Tanggal 22 September 2004. Tambahan Lembaran Negara Republik Indonesia

Undang-Undang Republik Indonesia Nomor 35 Tahun 2009 tentang Narkotika. Lembaran Negara Republik Indonesia Tahun 2009 Nomor 143. Tambahan Lembaran Negara Republik Indonesia Nomor 5062.

Undang-Undang Republik Indonesia Nomor 31 Tahun 2014 tentang Perubahan Atas UU No.13 Tahun 2006 tentang Perlindungan Saksi dan Korban. Lembaran Negara Republik Indonesia Tahun 2014 Nomor 293 Tanggal 17 Oktober 2014. Tambahan Lembaran Negara Republik Indonesia Nomor 5602.

Undang-Undang Republik Indonesia Nomor 10 Tahun 2016 tentang Pilkada. Lembaran Negara Republik Indonesia Tahun 2016 
Jurnal Hukum Saraswati (JHS),Volume. 03, Nomor 02, (2021) FAKULTAS HUKUM UNMAS DENPASAR ISSN (Cetak) : 2715-758X ISSN (Online): 2720-9555

Doi: https://doi.org/10.36733/jhshs.v2i2 https://e-journal.unmas.ac.id/index.php/JHS

91

Nomor 130, Tanggal 1 Juli 2016.

Tambahan Lembaran Negara

Republik Indonesia Nomor 5898.

Undang-Undang Republik Indonesia

Nomor 17 Tahun 2016 tentang

Undang-Undang.

Lembaran

Negara Republik Indonesia Tahun 2016 Nomor 99, Tanggal 25 Mei 2016. Tambahan Lembaran Penetpan Perpu No.1 Tahun 2016 tentang Perubahan Kedua UU No.23 Tahun 2002 tentang Penetapan Presiden Republik Indonesia Perlindungan Anak Menjadi Nomor 2 Tahun 1964 tentang Pelaksanaan Pidana Mati 